\title{
Abnormal Growth of Tissues Infected with Plasmodiophora brassicae
}

\author{
By D. S. INGRAM* \\ Department of Botany, University of Glasgow
}

(Accepted for publication 28 November 1968)

\begin{abstract}
SUMMAR Y
Clubroot formation on Sinapis alba plants infected with Plasmodiophora brassicae was not prevented by application of 2,3,5-triiodobenzoic acid or $\alpha$-naphthylphthalamic acid (inhibitors of polar transport of auxins in plants) to the hypocotyls. However, the fresh weight of club tissue produced on treated plants was lower than on untreated plants. This difference in weight was of the same order as the difference in total fresh weights of treated and untreated plants. Explants of tumour tissue from two Brassica species infected with $P$. brassicae, unlike explants from healthy roots, produced callus on a tissue culture medium without growth substances. Callus growth from infected tissues depended on the presence of active vegetative plasmodia in the cells. Established clones of Brassica rapa (Golden Ball) callus infected with vegetative plasmodia of $P$. brassicae, unlike healthy callus clones, grew well on a series of media deficient in one or more growth substances. Growth of infected Golden Ball callus on medium without growth substances was prevented by the tryptamine antagonist xylamidine tosylate and by the monoamine oxidase inhibitor iproniazid. Inhibition was annulled by including auxins or coconut milk in the medium. The relevance of these findings to abnormal growth of Brassica roots infected with $P$. brassicae is discussed.
\end{abstract}

\section{INTRODUCTION}

Disturbance of the phytohormone levels in host tissues is frequently an important consequence of infection of plants by many obligate and other fungal parasites (Brian, 1967). Changes in the levels of indoleacetic acid (IAA) and gibberellins are often involved (Sequeira, I963; Shaw, I963; Bailiss \& Wilson, 1967). Moreover, there is evidence that cytokinins are implicated in the disease syndromes resulting from rust and powdery mildew infections (Brian, 1967). The possible importance of such disturbances in understanding the nature of obligate parasitism has been discussed by Thrower (1965), Heitefuss (1966) and Brian (1967).

Tumorous growth of roots and hypocotyls, resulting from cellhypertrophy and hyperplasia, is the most striking feature of Brassica plants infected with Plasmodiophora brassicae. Changes in the phytohormone levels of the diseased tissues are clearly involved. Indeed, Katsura, Egawa, Toki \& Iishii (I966) have detected higher than normal levels of two growth substances, one thought to be IAA, in clubroot galls on Brassica rapa roots, and Williams (1966) has correlated cell and nuclear volumes of $B$. oleracea var. capitata cells, infected with $P$. brassicae, with the quantity of parasite within those cells. Williams suggested that the stimulus for cell division and

* Present address: Botany School, Downing Street, Cambridge, CB $2{ }_{3}$ EA. 
cell hypertrophy in clubroot galls lies within the parasitized cells and is not transferred to adjacent cells. Experiments are reported here which test the possibility that $P$. brassicae infected roots act as sinks for growth substances produced in the aerial parts of the plants, and tests are described where callus cultures, derived from roots of Brassica spp. infected with $P$. brassicae, were grown on tissue culture media deficient in one or more growth substances.

\section{METHODS}

Organisms. Plasmodiophora brassicae strain s (Ingram, 1969) was used throughout. Infected and healthy plants of Brassica oleracea var. capitata (Early Drumhead cabbage) and B. rapa (Balmoral turnip) were grown in soil according to the method of Ingram (1969). The procedure used for growing healthy and infected plants of Sinapis $a l b a$ is described below. The clones of $B$. rapa (Golden Ball turnip) callus used in tissue culture growth experiments had been cultured continuously on coconut milk medium (see below) for 9 months. Uninfected callus clones had been derived from surface-sterilized roots of healthy plants and infected callus clones had been derived from 5-week-old $P$. brassicae clubs and manipulated to contain only the vegetative plasmodial stage of the parasite life-cycle (Ingram, 1969). A further Golden Ball callus clone (GBA 4), which at the time of the experiments did not contain P. brassicae, was also 9 months old and had been established from a clubroot gall. Plasmodia had been present in the tissues for 3 months following callus initiation, but had then been lost from the cells.

2,3,5-Triiodobenzoic acid (TIBA) and $\alpha$-naphthylphthalamic acid (NPA) experiments. Sinapis alba seeds were germinated in sterilized soil at $20^{\circ}$ in a growth cabinet (Ingram, Knights, McEvoy \& McKay, I968) operated on alternating $8 \mathrm{hr}$ light and I6 hr dark periods (Sinapis alba does not flower in short days). Seedlings were transplanted singly, after 7 days, to 3.5 inch pots containing sterilized soil or soil infected with $10^{8}$ spores of Plasmodiophora brassicae per g. Hypocotyls of experimental plants were ringed, 3 days after transplanting, with lanolin paste containing TIBA (0.4 and $0.8 \%$ ) or NPA $(0.4 \%)$. Hypocotyls of control plants were ringed at the same time with pure lanolin paste. Lanolin rings were renewed every 5 days and all treatments were replicated Io times. Experiments were harvested 28 days after transplanting the seedlings and growth was assessed by measuring the height of plants from cotyledons to apex, counting the number of internodes and by fresh weights. The upper green parts of plants, and the roots or clubs (including hypocotyls) were weighed separately. Before weighing, roots and clubs were washed free of soil and blotted dry. In one experiment the effects of TIBA and NPA on flowering of Sinapis alba was determined by growing plants in alternating $\mathrm{I} 6 \mathrm{hr}$ light and $8 \mathrm{hr}$ dark periods.

Tissue culture experiments. Tissue cultures were incubated at $26^{\circ}$, in a growth room lit by a single, I00 W. tungsten lamp, on a basal medium of salts, micronutrients, vitamins, sucrose and agar (Ingram, I969) with the following additives: A, no additives, B, $\alpha$-naphthylacetic acid (NAA) $0.5 \mathrm{mg}$./1. + kinetin $1.0 \mathrm{mg} . / 1$; C, kinetin I.0 mg./l.; D, NAA $0.5 \mathrm{mg}$./1.; E, coconut milk I $50 \mathrm{ml}$./1. +2,4-dichlorophenoxyacetic acid (2,4-D) 6.0 mg./1. + NAA 0.I mg./1.; F, coconut milk I $50 \mathrm{ml} . / 1 . ; \mathrm{G}$, 2,4-D 6.0 mg./ 1. + NAA $0 . \mathrm{I} \mathrm{mg./1.} \mathrm{The} \mathrm{pH} \mathrm{of} \mathrm{all} \mathrm{media} \mathrm{was} \mathrm{adjusted} \mathrm{to} 5.5$ with $\mathrm{NaOH}$ or $\mathrm{HCl}$ before autoclaving at $115^{\circ}$ for $10 \mathrm{~min}$.

Tissue culture initiation tests. $1 \cdot 0 \mathrm{~mm} .{ }^{3}$ inocula taken from surface, sterilized 6-week- 
old clubs or healthy roots of Brassica oleracea var. capitata (Drumhead) and B. rapa (Balmoral) were incubated singly on $15 \mathrm{ml}$. of medium A or medium $\mathrm{E}$ (see above) contained in $25 \mathrm{~mm} . \times 150 \mathrm{~mm}$. Pyrex glass test tubes. Tests were also done using $0.5 \mathrm{~cm}$. root tip segments from healthy, 7 -day-old sterile seedlings of $B$. oleracea var. capitata (Drumhead) as inocula. Histological techniques used in these tests, surface sterilization procedures and preparation of sterile seedlings have been described by Ingram (1969).

Growth tests using established clones of Brassica rapa (Golden Ball) callus. The growth of healthy and Plasmodiophora brassicae infected callus of $B$. rapa (Golden Ball) was compared on media A, B, C, D, E, F, and G (see above). Explants (I.5 mm. ${ }^{3}$ ) of callus were transferred to basal medium for I week before commencement of the tests and then singly to $15 \mathrm{ml}$. batches of the test media contained in $25 \mathrm{~mm}$. $\times 150 \mathrm{~mm}$. culture tubes. Growth was normally assessed visually and by fresh and dry weights after eight I-week transfers on the test media. The growth of Golden Ball callus clone GBA 4 tissue was compared, using techniques similar to those described above, on media $\mathrm{A}$ and $\mathrm{E}$.

Experiments with xylamidine tosylate $(X T)$ and isonicotinic acid-2-isopropyl hydrazide (iproniazid). The effects of XT and iproniazid on growth of infected Brassica rapa (Golden Ball) callus on media A, E, F and G (see above) was investigated using $100 \mathrm{ml}$. Erlenmeyer flasks containing $20 \mathrm{ml}$. medium inoculated with three $\mathrm{I} \cdot 5 \mathrm{~mm} .^{3}$ explants of callus (maintained on basal medium for I week before commencement of the experiments). XT was added to sterile media, having first been dissolved in a little $95 \%(\mathrm{v} / \mathrm{v})$ ethanol in water and then taken up in a large volume of distilled water and sterilized by membrane filtration. Control media, which did not contain XT, were supplemented with ethanol equivalent to that in the XT solution. Iproniazid was also added to sterile media, having first been dissolved in distilled water and sterilized by membrane filtration. In some experiments media were also supplemented with tryptamine hydrochloride (dissolved in water, sterilized by membrane filtration); with a amino acid mixture based on an analysis of the amino acids of coconut milk done by Tulecke, Weinstein, Rutner \& Laurencot (196I) (dissolved in water and added before autoclaving); with Difco pure Casamino acids (added as a solid before autoclaving); and with 1,3-diphenylurea (added before autoclaving). In all experiments calluses were transferred to fresh medium each week and growth was assessed by fresh and dry weights.

\section{RESULTS}

Effects of 2,3,5-triiodobenzoic acid (TIBA) and $\alpha$-naphthylphthalamic acid (NPA) on the development of clubroot in intact plants of Sinapis alba

Both TIBA and NPA interfere with the polar transport of auxins in plants (Niedergang-Kamien \& Skoog, 1956; Morgan, I964; Keitt \& Baker, I966). TIBA may operate by immobilizing auxin, thus reducing the amount available for transport (Winter, I967a; Goldsmith, I968).

TIBA and NPA had similar and marked effects on the vegetative growth of Sinapis alba plants maintained in infected and sterilized soil (P1. I, fig. I). Compared with untreated control plants these effects were: height was reduced by over $50 \%$ (Tables $I, 2)$; leaves were reduced in area and were darker green than normal; dormancy of cotyledonary and axillary buds was broken and treated plants had two to six branches; 
total fresh weight was reduced by as much as $60 \%$ (Tables I, 2); an abnormal swelling of the hypocotyls developed immediately above the point of application of TIBA or NPA, while the region below this point had a much smaller diameter than control hypocotyls; and the onset of flowering by plants grown in long days was delayed by 7 to 10 days, while those flowers which did develop were dwarfed. The number of internodes produced by $S$. alba plants (normally between 10 and 13 internodes per plant) was not affected by TIBA or NPA.

Table I. The effect of 2,3,5-triiodobenzoic acid (TIBA) on Sinapis alba plants grown for 35 days in sterilized soil and in soil infected with resting spores of Plasmodiophora brassicae (short days)

Club and root weights as percentages of the mean total fresh weights of plants are given in parentheses (weights and heights are the means of ten replicates).

\begin{tabular}{|c|c|c|c|}
\hline \multirow[b]{2}{*}{ Treatment } & \multicolumn{2}{|c|}{ Mean fresh weights (g.) } & \multirow{2}{*}{$\begin{array}{c}\text { Mean } \\
\text { heights }(\mathrm{cm} .)\end{array}$} \\
\hline & Tops & Clubs or roots & \\
\hline $\begin{array}{c}\text { Sterilized soil } \\
\text { Pure lanolin } \\
0.4 \% \text { TIBA } \\
0.8 \% \text { TIBA }\end{array}$ & $\begin{array}{r}18.3 \pm 0.8 \\
7.3 \pm 0.6 \\
6.7 \pm 0.4\end{array}$ & $\begin{array}{l}I .0 \pm 0 . I \quad(5.2 \%) \\
0.2 \pm 0.02(2.2 \%) \\
0.1 \pm 0.02(2.0 \%)\end{array}$ & $\begin{array}{r}17.3 \pm 0.8 \\
9.6 \pm 0.5 \\
9.4 \pm 0.6\end{array}$ \\
\hline $\begin{array}{l}\text { Infected soil } \\
\text { Pure lanolin } \\
0.4 \% \text { TIBA } \\
0.8 \% \text { TIBA }\end{array}$ & $\begin{array}{r}10.2 \pm 0.4 \\
4.6 \pm 0.5 \\
4.6 \pm 0.4\end{array}$ & $\begin{array}{l}2.2 \pm 0.4(16.6 \%) \\
0.9 \pm 0.2(16.2 \%) \\
I . I \pm 0.1(18.9 \%)\end{array}$ & $\begin{array}{r}15 \cdot 1 \pm 0.9 \\
8 \cdot 1 \pm 0.5 \\
8 \cdot 2 \pm 0.4\end{array}$ \\
\hline
\end{tabular}

Table 2. The effect of $\alpha$-naphthylphthalamic acid (NPA) on Sinapis alba plants grown for 35 days in sterilized soil and soil infected with resting spores of Plasmodiophora brassicae (short days)

Club and root weights as percentages of the mean total fresh weights of plants are given in parentheses (weights and heights are the means of ten replicates).

\begin{tabular}{|c|c|c|c|}
\hline \multirow[b]{2}{*}{ Treatment } & \multicolumn{2}{|c|}{ Mean fresh weights (g.) } & \multirow{2}{*}{$\begin{array}{c}\text { Mean } \\
\text { heights }(\mathrm{cm} .)\end{array}$} \\
\hline & Tops & Clubs or roots & \\
\hline $\begin{array}{c}\text { Sterilized soil } \\
\text { Pure lanolin } \\
0.4 \% \text { NPA }\end{array}$ & $\begin{array}{r}16.9 \pm 0.5 \\
5.0 \pm 0.8\end{array}$ & $\begin{array}{l}I \cdot I \pm 0.04(6 . I \%) \\
0 . I \pm 0.04(2.8 \%)\end{array}$ & $\begin{array}{r}22 \cdot 1 \pm 0.7 \\
8 \cdot 9 \pm 4 \cdot 4\end{array}$ \\
\hline $\begin{array}{l}\text { Infected soil } \\
\text { Pure lanolin } \\
0.4 \% \text { NPA }\end{array}$ & $\begin{array}{r}\text { II } \cdot 0 \pm 0.6 \\
3.5 \pm 0.4\end{array}$ & $\begin{array}{l}2.8 \pm 0.3(20.2 \%) \\
0.6 \pm 0.1(15.1 \%)\end{array}$ & $\begin{array}{r}17 \cdot 2 \pm 1 \cdot 0 \\
8.6 \pm 0.7\end{array}$ \\
\hline
\end{tabular}

Concentration of NPA is given as $\%(w / w)$ in lanolin paste.

The fresh weight of Plasmodiophora brassicae clubs formed on TIBA-and NPAtreated plants grown in infected soil was much lower than the weight of clubs formed on control plants (Tables I and 2). In the case of TIBA treated plants this difference in weight, however, was of the same order as the difference between the total fresh weights of treated and control plants. Clubroot tissue accounted for $16.6 \%$ of the mean total weight of control plants compared with 16.2 and $18.9 \%$ of the mean total weights of plants treated with 0.4 and $0.8 \%$ TIBA in lanolin respectively. In the case of NPA-treated plants clubroot tissue accounted for $20.2 \%$ of the mean total weight of control plants and for only $15.1 \%$ of the mean total weight of plants treated with 
$0.4 \%$ NPA in lanolin. However, it is notable that both TIBA and NPA led to marked reductions in the percentage fresh weights of healthy roots of uninfected plants, compared with controls (Tables I and 2).

\section{Callus culture initiation by clubroot tissues on basal medium}

Tissue culture initiation by $1.0 \mathrm{~mm} .^{3}$ explants of 5 -week-old clubroot tissue and 5-week-old healthy root tissue of Brassica oleracea var. capitata (Drumhead) and of B. rapa (Balmoral) was compared on basal medium (A) and on coconut milk-2,4-DNAA medium (E) (Table 3 and Pl. I, fig. 2). The clubroot tissues formed callus after 4 to 7 days' incubation on both media. This growth continued for 4 to 6 weeks, then darkening of the tissues occurred and growth ceased. On medium $E$ new callus formed on the degenerate tissues after a short time and continued to develop uninterrupted (Ingram, I969). On basal medium, however, roots began to form immediately on about $50 \%$ of the apparently dead calluses and continued to grow for approximately 4 weeks, then organized root growth ceased. Those roots which were already formed became disorganized and further growth was in the form of slow growing callus which, in the case of Balmoral, was maintained for I8 months on basal medium.

Table 3. Callus initiation by healthy and Plasmodiophora brassicae infected Brassica rapa (Balmoral Turnip) root tissue explants on basal medium and on coconut milk medium

Where appropriate, the mean fresh weight of calluses is given in mg. Callus growth: -, no growth; + , slow growth; ++ , good growth; +++ , vigorous growth.

Callus growth

\begin{tabular}{|c|c|c|c|c|}
\hline \multirow[b]{2}{*}{$\begin{array}{l}\text { Days on } \\
\text { medium }\end{array}$} & \multicolumn{2}{|c|}{ Healthy } & \multicolumn{2}{|c|}{ Infected } \\
\hline & $\begin{array}{l}\text { Basal } \\
\text { medium }\end{array}$ & $\begin{array}{l}\text { Coconut milk } \\
\text { medium }\end{array}$ & $\begin{array}{l}\text { Basal } \\
\text { medium }\end{array}$ & $\begin{array}{l}\text { Coconut milk } \\
\text { medium }\end{array}$ \\
\hline 7 & - & + & ++ & ++ \\
\hline 18 & - & + & $\begin{array}{c}+++ \\
(29 \cdot 5 \pm 5 \cdot 7)^{*}\end{array}$ & $\begin{array}{c}+++ \\
(57 \cdot 9 \pm 12.5) \dagger\end{array}$ \\
\hline 50 & - & $\begin{array}{c}+++ \\
(50 \cdot 1 \pm 6 \cdot 6) \ddagger\end{array}$ & $\begin{array}{l}\text { Callus degenerate, } \\
\text { roots developing }\end{array}$ & Callus degenerate \\
\hline $50>$ & - & $\begin{array}{l}\text { Continuing } \\
\text { vigorous callus } \\
\text { growth }\end{array}$ & $\begin{array}{l}\text { Callus growth } \\
\text { from roots } \\
\text { continuing } \\
\text { slowly }\end{array}$ & $\begin{array}{l}\text { Regrowth of } \\
\text { callus, con- } \\
\text { tinuing slowly }\end{array}$ \\
\hline
\end{tabular}

Tissue cultures could not be initiated easily from roots of healthy soil grown Drumhead plants because of contamination by endogenous micro-organisms. However, those tissue inocula which were contamination free did not form callus on basal medium, although vigorous callus growth did take place on medium E. Further, $\mathrm{I} \cdot \mathrm{O} \mathrm{cm}$. long root tip segments from healthy, sterile Drumhead seedlings continued to develop as roots on basal medium and only gave rise to callus on medium $\mathrm{E}$. Healthy Balmoral root tissue explants did not form callus on basal medium, but on medium E callus began to develop slowly after I week and proliferated rapidly, without interruption, after 7 weeks.

Sections of Drumhead and Balmoral tissues grown on basal medium showed that 
the development of Plasmodiophora brassicae within the tissues was similar to the development of the parasite in infected Brassica tissues grown on medium E (Ingram, 1968). At the time of tissue culture initiation most plasmodia in the explants were at an advanced stage of development, with many nuclei. Callus produced on the inocula did not become infected with the parasite immediately, and infected cells did not divide. Callus decline coincided with resting spore formation in the cells of the explant region of the tissue mass. Roots which formed on the cultures became infected with vegetative plasmodia after the resting spores had germinated in situ to give primary (root hair) plasmodia and zoosporangia first. Disorganization of the roots to give callus tissue commenced when vegetative plasmodia reappeared in the tissues. Balmoral callus grown on basal medium for 12 months contained all stages of the $P$. brassicae life-cycle.

\section{Growth of Brassica rapa (Golden Ball) callus, infected with vegetative plasmodia, on media deficient in growth substances}

Callus growth from explants of 9-month-old, established Brassica rapa (Golden Ball) callus infected with vegetative Plasmodiophora brassicae plasmodia and from healthy callus explants of this species was compared on basal medium and on basal medium supplemented with one or more growth substances (media A to G). The results of these tests are summarised in Table 4 and Pl. 2, fig. 3 and 4.

Table 4. Mean fresh and dry weights of callus produced by explants of healthy and Plasmodiophora brassicae plasmodia infected callus of Brassica rapa (Golden Ball Turnip) on basal and other media

\begin{tabular}{|c|c|c|c|c|}
\hline \multirow[b]{3}{*}{ Supplements to basal medium } & \multicolumn{4}{|c|}{ Weight of callus (mg.) } \\
\hline & \multicolumn{2}{|c|}{ Healthy* } & \multicolumn{2}{|c|}{ Infected $\dagger$} \\
\hline & Fresh weight & Dry weight & Fresh weight & Dry weight \\
\hline $\begin{array}{l}\text { None } \\
\mathrm{I} \cdot 0 \mathrm{mg} . / 1 . \text { kinetin }+0.5 \mathrm{mg} . / 1 . \mathrm{NAA}\end{array}$ & $\begin{array}{c}\text { No growth } \\
76 \cdot 2 \pm 6 \cdot 1\end{array}$ & $\begin{array}{l}\text { No growth } \\
8 \cdot 4+I \cdot I\end{array}$ & $\begin{array}{l}116.5 \pm 23.6 \\
216.6 \pm 27.9\end{array}$ & $\begin{array}{l}I 5 \cdot 8 \pm 8 \cdot 5 \\
24 \cdot 7 \pm 2 \cdot 6\end{array}$ \\
\hline I $\circ \mathrm{mg} . / \mathrm{l}$. kinetin & No growth & No growth & $\mathrm{I} 40.5 \pm 23.5$ & $16 \cdot 4 \pm 2.5$ \\
\hline $0.5 \mathrm{mg} . / 1$. NAA & $87 \cdot 7 \pm 15 \cdot 8 \ddagger$ & $8 \cdot 6 \pm I \cdot 7 \ddagger$ & $174.3 \pm 23.9$ & $19 \cdot 4 \pm 2 \cdot 0$ \\
\hline $\begin{array}{l}6.0 \mathrm{mg} . / 1.2,4-\mathrm{D}+0.1 \mathrm{mg} . / \mathrm{l} . \mathrm{NAA}+ \\
\text { I } 50 \mathrm{ml} . / 1 . \text { coconut milk }\end{array}$ & $411 \cdot 7 \pm 15 \cdot 3$ & $36 \cdot 0 \pm I \cdot 3$ & $409 \cdot I \pm 13 \cdot 6$ & $38 \cdot 2 \pm I \cdot 5$ \\
\hline $\begin{array}{l}\text { I } 50 \mathrm{ml} . / 1 . \text { coconut milk } \\
6.0 \mathrm{mg} . / \mathrm{l} .2,4-\mathrm{D}+0.1 \mathrm{mg} . / 1 . \text { NAA }\end{array}$ & $\begin{array}{l}82 \cdot 2 \pm 10 \cdot 1 \ddagger \\
124 \cdot 1 \pm 8 \cdot 7\end{array}$ & $\begin{array}{l}7 \cdot 7 \pm I \cdot I \ddagger \\
15 \cdot 3 \pm 1 \cdot 0\end{array}$ & $\begin{array}{l}349 \cdot 3 \pm 36 \cdot 2 \\
179 \cdot 2 \pm 20 \cdot 5\end{array}$ & $\begin{array}{l}34 \cdot 4 \pm 2 \cdot 4 \\
16 \cdot 0 \pm 2 \cdot 2\end{array}$ \\
\hline
\end{tabular}

* Ten replicates. † Five replicates. $\ddagger$ One to six short roots formed on each explant.

Growth of healthy callus. Explants of healthy Golden Ball callus tissue did not continue to grow after transfer to basal medium (A). However, some callus growth did occur on basal medium supplemented with both NAA $0.5 \mathrm{mg} . / 1$. and kinetin I. $\circ \mathrm{mg}$./l. (B), although no growth occurred on basal medium supplemented with kinetin alone (C), while on basal medium supplemented with NAA alone (D) callus growth was poor and I to 6 short roots formed on each explant. On medium containing 2,4-D 6.0 mg./1., NAA $0.1 \mathrm{mg}$./1. and coconut milk (E) the explants produced a large amount of firm, healthy callus, and on medium containing 2,4-D and NAA but no coconut milk (G), callus growth was firm and healthy, although the bulk of tissue produced was only about half that produced on medium E. On medium supple- 
mented with coconut milk alone (F) callus growth was very poor and I to 6 short roots formed on each explant.

Growth of infected callus. Explants of Golden Ball callus tissue infected with vegetative plasmodia of Plasmodiophora brassicae were able to continue callus growth on all media tested, and roots were never produced. On basal medium (A) growth was slow and variable but always took place. Growth from the explants was rather better on medium containing NAA $0.5 \mathrm{~m} \mathrm{~g} . / 1$. and kinetin $\mathrm{r} .0 \mathrm{mg} . / \mathrm{l}$. (B), while on media containing kinetin alone (C) or NAA alone (D) callus growth was about the same as on basal medium. As with healthy tissues, good callus growth occurred on medium containing 2,4-D 6.0 mg./1., NAA $0^{\circ} \mathrm{I} \mathrm{mg}$. $/ 1$. and coconut milk (E). Unlike healthy tissues, however, infected tissue explants grew almost as well on basal medium supplemented with coconut milk alone (F) as on medium $\mathrm{E}$, while on medium containing 2,4-D and NAA but no coconut milk (G) growth was similar in bulk to that produced by healthy tissues on the same medium.

In one experiment the possibility that growth of infected tissues on the growth substance deficient media may have been supported by auxins or kinins carried over from the previous culture medium was tested. The results showed that callus growth continued without diminution for 16 I-weekly transfers on all of the test media.

Growth of clone GBA 4 callus on basal medium. Explants of clone GBA 4 of Brassica rapa (Golden Ball) callus, which had once contained Plasmodiopthora brassicae, did not make any growth when they were transferred to basal medium (A). The tissue was capable of good growth on coconut milk-2,4-D-NAA medium (E). There was no evidence that the GBA 4 tissues had any ability to grow on growth factor deficient media.

\section{Experiments with xylamidine tosylate}

Xylamidine tosylate (XT) antagonizes the peripheral effects of 5-hydroxytryptamine in isolated rat uterus and in various in vivo tests with rats (Copp, Green, Hodson, Randall \& Simm, 1967). It also antagonizes the tryptamine-stimulated growth of detached apices of Avena coleoptiles (Winter, $1967 b$ ). The effect of XT on proliferation of the infected Brassica rapa (Golden Ball) callus on basal medium was investigated.

Effective concentration. Growth of explants of infected Golden Ball callus tissue was compared on basal medium (A) supplemented with $0 \cdot 0,5^{\circ} 0,10 \cdot 0,20 \cdot 0$ and $40.0 \mathrm{mg}$. 11. XT (Table 5). Callus growth from the explants occurred on unsupplemented basal medium as in previous experiments and growth was not inhibited by $5.0 \mathrm{mg}$./1. XT. However, XT was slightly inhibitory to growth at the $10.0 \mathrm{mg} . / 1$. and $20.0 \mathrm{mg} . / 1$. concentrations, while at the $40.0 \mathrm{mg}$. $/ 1$. concentration callus growth was prevented completely.

Reversal of inhibition. Proliferation of infected Golden Ball callus tissue explants was compared on media A, E, F and G (see above), unsupplemented or supplemented with $50 \mathrm{mg}$./1. XT. The results of these tests are summarized in Table 6 and Pl. 2 . fig. 5. Growth of the callus on basal medium (A) was prevented completely by the presence of XT. However, XT had no marked inhibitory effect on callus proliferation on medium containing 2,4-D, NAA and coconut milk (E) or coconut milk alone (F), On medium containing 2,4-D and NAA, but no coconut milk (G), callus development was retarded to some extent by XT, although explants did produce some new tissue which, at the end of the experiment ( 6 weeks), was beginning to proliferate vigorously. 
Fresh hand sections of Golden Ball callus tissue grown on media containing XT gave no evidence that Plasmodiophora brassicae plasmodia in the cells had been killed.

Effect of other compounds on xylamidine tosylate inhibited growth. I,3-diphenylurea (DPU), a constituent of coconut milk, is stimulatory to cell division in carrot root tissue explants when $2.0 \mathrm{mg}$./l. are included in a basal medium supplemented with $200 \mathrm{mg} . / 1$. casein hydrolysate (Shantz \& Steward, 1955). However, DPU (2.0 mg./1.), Casamino acids (200 mg./1.) and an amino acid mixture (Tulecke et al. 1961), alone and in combination, did not reverse the inhibition of growth of infected Golden Ball callus on basal medium (A) containing $50.0 \mathrm{mg}$./1. XT. There was some slight indication in another experiment that DPU at a concentration of at least $20.0 \mathrm{mg}$./ 1 ., in combination with $200 \mathrm{mg}$./1. Casamino acids, was partially effective in reversing the XT inhibition, but no consistent results were obtained.

Table 5. The mean weights of 15 replicate calluses of Brassica rapa (Golden Ball Turnip), infected with Plasmodiophora brassicae plasmodia, after 5 weeks of growth on basal medium supplemented with various concentrations of xylamidine tosylate

\begin{tabular}{ccc}
$\begin{array}{c}\text { Concentration } \\
\text { of xylamidine } \\
\text { tosylate } \\
\text { (mg./l.) }\end{array}$ & \multicolumn{2}{c}{ Weight of callus (mg.) } \\
\cline { 2 - 3 } 0 & Fresh & Dry \\
$5 \cdot 0$ & $66 \cdot 0 \pm 6 \cdot 0$ & $7 \cdot 3 \pm 0 \cdot 8$ \\
$10 \cdot 0$ & $66 \cdot 1 \pm 7 \cdot 0$ & $8 \cdot 4 \pm \mathrm{I} \cdot 0$ \\
$20 \cdot 0$ & $54 \cdot 3 \pm 6 \cdot 5$ & $6 \cdot 4 \pm 0 \cdot 8$ \\
$40 \cdot 0$ & $43 \cdot 3 \pm 6 \cdot 3$ & $5 \cdot 9 \pm \mathrm{I} \cdot \mathrm{I}$ \\
& No growth & No growth
\end{tabular}

Table 6. Mean fresh and dry weights of Io replicate calluses of Brassica rapa (Golden Ball Turnip), infected with Plasmodiophora brassicae plasmodia, after 6 weeks of growth on basal and other media, unsupplemented and supplemented with $50 \mathrm{mg}$ l. xylamidine tosylate.

\begin{tabular}{|c|c|c|c|c|}
\hline \multirow{3}{*}{$\begin{array}{l}\text { Additives to } \\
\text { basal medium }\end{array}$} & \multicolumn{4}{|c|}{ Mean weight of calluses (mg.) } \\
\hline & \multicolumn{2}{|c|}{ Without xylamidine tosylate } & \multicolumn{2}{|c|}{ With xylamidine tosylate } \\
\hline & $\begin{array}{c}\text { Fresh } \\
96 \cdot 2 \pm 11 \cdot 6\end{array}$ & $\begin{array}{c}\text { Dry } \\
13 \cdot 1 \pm 1 \cdot 7\end{array}$ & $\begin{array}{c}\text { Fresh } \\
\text { No growth }\end{array}$ & $\begin{array}{l}\text { Dry } \\
\text { No growth }\end{array}$ \\
\hline $\begin{array}{l}150 \mathrm{ml} . / 1 . \text { coconut milk }+ \\
6.0 \mathrm{mg} . / 1.2,4-\mathrm{D}+0.1 \mathrm{mg} . / 1 \text {. } \\
\text { NAA }\end{array}$ & $323 \cdot 8 \pm 13 \cdot 3$ & $27 \cdot 6 \pm I \cdot I$ & $328 \cdot 7 \pm 12.5$ & $3 I \cdot 2 \pm 9 \cdot 6$ \\
\hline I50 ml./1. coconut milk & $279 \cdot 0 \pm 25 \cdot 6$ & $32 \cdot 7 \pm 4 \cdot 6$ & $266 \cdot 0 \pm 28 \cdot 5$ & $32 \cdot 1 \pm 3 \cdot 8$ \\
\hline $\begin{array}{l}\text { 6.0 mg./1. 2,4-D + 0.I mg./l. } \\
\text { NAA }\end{array}$ & I I $5 \cdot 5 \pm 12 \cdot I$ & $12 \cdot 6 \pm I \cdot 0$ & $42 \cdot 9 \pm 4 \cdot 2^{*}$ & $6 \cdot 1 \pm 4 \cdot 4^{*}$ \\
\hline
\end{tabular}

Tryptamine hydrochloride at $2 \cdot 5,5 \cdot 0,10 \cdot 0,20 \cdot 0$ and $40 \cdot 0 \mathrm{mg} . / 1$. was tested for its ability to prevent inhibition of infected Golden Ball callus growth on basal medium (A) by XT. Although the experiment was repeated several times no evidence was obtained that inhibition was prevented by this compound at any of the concentrations listed. 


\section{Experiments with iproniazid}

Amine oxidase inhibitors prevent the formation of indoleacetic acid from tryptamine (Perley \& Stowe, 1966) and inhibit tryptamine-stimulated growth of excised Avena coleoptile apices (Winter, 1966). Iproniazid is an inhibitor of monoamine oxidase in animal tissue (Zeller \& Sarker, 1962). Growth of explants of Brassica rapa (Golden Ball) callus, infected with vegetative Plasmodiophora brassicae plasmodia, was compared on media A, E, F and G (see above) all supplemented with $0.0,50 \cdot 0$ or $100 \cdot 0 \mathrm{mg}$./ 1. iproniazid (Table 7). At the $50 \mathrm{mg}$./1. concentration iproniazid was not markedly inhibitory to growth of infected callus explants on any of the media tested. However, at the $100 \mathrm{mg}$./1. concentration iproniazid inhibited callus growth completely on basal medium (A) but only slightly on media containing coconut milk and auxins, alone and in combination ( $E$ to $G$ ).

Table 7. Mean fresh and dry weights of to replicate calluses of Brassica rapa (Golden Ball Turnip), infected with Plasmodiophora brassicae plasmodia, after 6 weeks of growth on basal and other media, unsupplemented and supplemented with iproniazid

\begin{tabular}{|c|c|c|c|}
\hline \multirow[b]{2}{*}{ Additives to basal medium } & \multirow{2}{*}{$\begin{array}{l}\text { Concentration } \\
\text { of iproniazid } \\
\text { (mg./l.) }\end{array}$} & \multicolumn{2}{|c|}{ Mean weights of calluses (mg.) } \\
\hline & & Fresh & Dry \\
\hline None & $\begin{array}{r}0 \\
50 \\
100\end{array}$ & $\begin{array}{r}91 \cdot 9 \pm 6 \cdot 6 \\
63 \cdot 7 \pm 6 \cdot 8 \\
\text { No growth }\end{array}$ & $\begin{array}{c}10.4 \pm 0 \cdot 9 \\
9 \cdot 8 \pm I \cdot 2 \\
\text { No growth }\end{array}$ \\
\hline $\begin{array}{l}150 \mathrm{ml} . / 1 . \text { coconut milk }+ \\
6.0 \mathrm{mg} . / 1.2,4-\mathrm{D}+0 \cdot \mathrm{I} \mathrm{mg} . / 1 \text {. } \\
\text { NAA }\end{array}$ & $\begin{array}{r}0 \\
50 \\
100\end{array}$ & $\begin{array}{l}I 80 \cdot 4 \pm I 5 \cdot 4 \\
I 80 \cdot I \pm I 5 \cdot 8 \\
I 4 I \cdot 9 \pm 17 \cdot 4\end{array}$ & $\begin{array}{l}17 \cdot 0 \pm 0 \cdot 7 \\
15 \cdot 5 \pm 1 \cdot 3 \\
14 \cdot 1 \pm 2 \cdot 0\end{array}$ \\
\hline I $50 \mathrm{ml} . / 1$. coconut milk & $\begin{array}{r}0 \\
50 \\
100\end{array}$ & $\begin{array}{l}177 \cdot 5 \pm 17 \cdot 1 \\
150 \cdot 7 \pm 13 \cdot 9 \\
157 \cdot 9 \pm 10 \cdot 9\end{array}$ & $\begin{array}{l}19 \cdot 9 \pm 2 \cdot 4 \\
16 \cdot 8 \pm 1 \cdot 3 \\
15 \cdot 7 \pm I \cdot 3\end{array}$ \\
\hline $\begin{array}{l}6.0 \mathrm{mg} . / 1.2,4-\mathrm{D}+0.1 \mathrm{mg} . / 1 . \\
\text { NAA }\end{array}$ & $\begin{array}{r}0 \\
50 \\
100\end{array}$ & $\begin{array}{l}82 \cdot 2 \pm I I \cdot 9 \\
80 \cdot 2 \pm 4 \cdot 9 \\
54 \cdot 8 \pm I 6 \cdot I\end{array}$ & $\begin{array}{l}7 \cdot 9 \pm I \cdot I \\
7 \cdot 8 \pm 0 \cdot 7 \\
6 \cdot 0 \pm I \cdot 2\end{array}$ \\
\hline
\end{tabular}

\section{DISCUSSION}

Sandstedt \& Schuster (1966) suggested that gall formation in plants infected with Meloidogyne incognita may occur because this nematode enables the infected tissues to retain and use auxin which might otherwise be transported elsewhere in the plant. The possibility that Plasmodiophora brassicae might act as a sink for growth substances produced in the aerial parts of infected plants was tested by ringing Sinapis alba plants growing in infected soil with 2,3,5-triiodobenzoic acid (TIBA) and $\alpha$-naphthylphthalamic acid (NPA). Both compounds have been reported to prevent the polar transport of auxins in plant tissues, although there is no direct evidence that they have this effect in $S$. alba.

The experiments did indicate that the distribution of auxins, and possibly gibberellins, in Sinapis ala was affected by TIBA and NPA, resulting in such marked changes in the treated plants as reduced internode length and breaking of apical dominance. The formation of clubs on the $S$. alba plants was not prevented by the TIBA or NPA treatments, although the fresh weight of both club tissue and root tissue produced on treated plants was considerably lower than on untreated plants. Similar results were obtained when TIBA was applied to the hypocotyls of infected Brassica oleracea var. 
capitata (Drumhead) plants in experiments not reported here. Neither the TIBA experiments nor the NPA experiments provided any clear evidence that Plasmodiophora brassicae infected root tissues of $S$. alba are able to act as a sink for growth substances produced in the aerial parts of the plant.

A probable explanation for the high levels of auxin found in clubbed roots of Brassica rapa by Katsura et al. (1966) is that growth substances are synthesized by Plasmodiophora brassicae, or by the host tissues in response to this pathogen, at or very close to the infection site. This probability is strongly supported by the demonstration that tissue explants from clubbed roots of $B$. oleracea var. capitata (Drumhead) and B. rapa (Balmoral), unlike tissue explants from uninfected roots of these species, were able to form callus on a medium which did not contain growth substances. Callus growth on this basal medium depended upon the presence of vegetative plasmodia in the cells. During the period when only resting spores were present callus growth was replaced by the formation of organized roots, indicative of a shift in the balance of growth substances in the callus mass. Roots on the infected tissues became disorganized and callus formation was resumed as soon as resting spores germinated in situ and vegetative plasmodia reappeared in the cells. These observations are in keeping with an unpublished observation of the author that callus tissues of many uninfected Brassica species initiate roots when transferred from a medium containing auxin and kinetin to a basal medium.

It appeared from the results discussed above that the presence of vegetative plasmodia of Plasmodiophora brassicae in Brassica tissues renders them independent of an exogenous supply of auxin and kinin for disorganized growth. This conclusion was further borne out in the experiments where growth of established, uninfected and plasmodially infected Brassica rapa (Golden Ball) callus was compared on a series of media deficient in one or more growth substances. Infected calluses were able to continue growth when transferred to a medium without growth substances, whereas uninfected calluses were not. There was little difference in the growth of infected and uninfected calluses on medium supplemented with 2,4-dichlorophenoxyacetic acid (2,4-D), $\alpha$-naphthylacetic acid (NAA) and coconut milk. However, the growth of infected tissues was markedly better on medium which did contain auxin and kinetin or auxin and coconut milk than on basal medium. Basal medium supplemented with coconut milk alone supported infected callus proliferation to the same extent as basal medium supplemented with both coconut milk and auxin. In contrast, medium containing coconut milk alone did not induce proliferation of uninfected callus, although a few root initials were formed. The possibility must be considered that the coconut milk contained auxin precursors available only to $P$. brassicae and not to the host tissues or, alternatively, that nutrients stimulatory to growth of the parasite were present. Tryptophan was not detected in an analysis of the amino acids of the coconut milk used in the experiments (C. Wheeler, using a Beckman 'Unichrom' autoanalyserpersonal communication), and tryptamine is unlikely to have been present since the coconut milk had twice been autoclaved at $115^{\circ}$ for $10 \mathrm{~min}$. at the time of the experiments. However, Shantz \& Steward (1955) have isolated the cell division factor I,3diphenylurea (DPU) from coconut milk. Tulecke $e$ t al. (I96I) identified a number of nutrients in coconut milk, any of which could have been stimulatory to $P$. brassicae. These nutrients included a number of organic acids: sugars such as sucrose, glucose, fructose, sorbitol; inositol; vitamins; and a wide range of amino acids. 
It is notable that uninfected Brassica rapa (Golden Ball) calluses were capable of some growth on basal medium supplemented with NAA alone, and grew quite well on medium containing NAA and 2,4 -D but no coconut milk, indicating that an exogenous supply of kinin was not esssntial for uninfected tissue proliferation. The experiment with Clone GBA 4 of $B$. rapa (Golden Ball), a callus clone from which $P$. brassicae had been lost, did not provide any evidence that the parasite has any ability to transform its host's cells to be independent of exogenous growth substances as is the case with the Crown Gall disease caused by Agrobacterium tumefaciens (Braun \& Lipetz, I966).

That the pathway to indoleacetic acid (IAA) was involved in the growth of Brassica rapa (Golden Ball) callus on basal medium was strongly suggested by the xylamidine tosylate (XT) and iproniazid experiments. Both XT, an antagonist of tryptamine stimulated growth in plants, and the monoamine oxidase inhibitor iproniazid prevented growth of the infected callus on basal medium, but not on basal medium supplemented with coconut milk and auxin, alone or in combination. It is interesting that coconut milk alone was more efficient in preventing the inhibition of infected callus growth by XT and iproniazid than was auxin alone. Although DPU is known to be present in coconut milk (Shantz \& Steward, 1955), this compound did not have any marked ability to prevent the inhibition of infected callus growth by XT in the basal medium, even when it was used in combination with Casamino acids. (An explanation for this result could be that it was difficult to obtain good dispersion of DPU in the tissue culture media.) Another possible reason for the efficiency of the coconut milk in preventing the inhibitory effects of XT and iproniazid is that it contained auxins or auxin precursors which were not susceptible to XT or iproniazid and were, therefore, available to the infected tissues for growth.

Wightman (1962) suggested that indoleacetonitrile (IAN) is an important intermediate in the biogenesis of IAA from tryptophan in cabbage. He was unable to name any of the intermediates in the formation of IAN itself, but did rule out the possibilities that tryptamine and indoleacetaldehyde were involved. Moreover, the mustard oil glucoside, glucobrassicin, has been isolated from cabbages (Gmelin \& Virtanen, 196I) and is thought to be a precursor of IAN and a storage form of auxin in Brassicas (Andersen, 1966). It is likely that these findings for cabbage could apply equally to other Brassica spp. such as Brassica rapa. Although it is known that xylamidine tosylate does prevent the conversion of tryptamine to IAA in Avena (Winter, $1967 b$ ), nothing is known regarding the specificity or the exact site of action of this compound. Further experiments where specific precursors of IAN and IAA, and other inhibitors of the enzymes involved in the biosynthesis of these compounds, are fed to Plasmodiophora brassicae-infected or uninfected Brassica tissues, or to isolated but living $P$. brassica plasmodia, could define more precisely the route by which auxins are synthesised in infected tissues. That the biosynthetic pathway involved is different from the pathway followed in uninfected tissues is possible.

I wish to thank Professor P. W. Brian for advice and discussions, Dr D. G. Morgan for $\alpha$-naphthylphthalamic acid, Dr H. F. Hodson for xylamidine tosylate, Dr C. Wheeler for carrying out an analysis of the amino acids of coconut milk, the Agricultural Research Council for financial support, and Mrs C. Breen for technical assistance. 


\section{REFERENCES}

ANDERSEN, A. S. (1966). Auxin physiology of glucobrassicin. Ph.D. thesis, University of Iowa.

BaILISS, K. W. \& WILSON, I. M. (1967). Growth hormones and the creeping thistle rust. Ann. Bot., Lond., N.S. 31, 195.

Braun, A. C. \& Lipetz, J. (1966). The use of tissue cultures in phytopathology. In Cells and Tissues in Culture. Ed. by E. N. Willmer, vol. III, p. 691. London: Academic Press.

Brian, P. W. (1967). Obligate parasitism in fungi. Proc. R. Soc. B, I68, I0I.

Copp, F. C., Green, A. F., Hodson, H. F., Randall, A. W. \& Simm, M. F. (1967). New peripheral antagonists of 5-hydroxytryptamine. Nature, Lond. 214, 200.

GMELIN, R. \& VIRTANEN, A. I. (I96I). Glucobrassicin, the precursor of 3-indolylacetonitrile, ascorbigen and $\mathrm{SCN}^{-}$in Brassica oleracea species. Acta chem. fenn. 34, I5.

Goldsmith, M. H. M. (1968). The transport of auxin. A. Rev. Pl. Physiol. 19, 347.

HeItefuss, R. (1966). Nucleic acid metabolism in obligate parasitism. A. Rev. Phytopath. 4, 22 I.

INGRAM, D. S. (1969). Growth of Plasmodiophora brassicae in host callus. J. gen. Microbiol. 55, 9.

Ingram, D. S., Knights, B. A., McEvoy, I. J. \& McKay, P. (I968). Studies in the Cruciferae. Changes in the composition of the sterol fraction following germination. Phytochemistry $7,1241$.

Katsura, K., Egawa, H., ToKI, T. \& IsHII, S. (1966). On the plant hormones in the healthy and Plasmodiophora infected roots of Brassica rapa var. neosuguki Kitam. (I). Ann. Phytopath. Soc. Japan 32, I 23.

KeItT, G. W. \& BaKer, R. A. (1966). Auxin activity of substituted benzoic acids and their effect on polar auxin transport. Pl. Physiol. Lancaster 4I, I56I.

MorGAN, D. G. (1964). Influence of $\alpha$-naphthylphthalamic acid on the movement of indolyl-3-acetic acid in plants. Nature, Lond. $207,476$.

Neidergang-Kamien, E. \& Skoog, F. (1956). Studies on polarity and auxin transport in plants. I. Modification of polarity and auxin transport by triiodobenzoic acid. Physiologia Plant. 9, 60.

Perley, J. E. \& Stowe, B. B. (1966). On the ability of Taphrina deformans to produce indoleacetic acid from tryptophan by way of tryptamine. Pl. Physiol. Lancaster 4r, 234.

SANDSTEDT, R. \& SCHUSTER, M. L. (1966). The role of auxins in root-knot nematode-induced growth on excised tobacco stem segments. Physiologia Plant. 19, 960.

SequeIRA, L. (1963). Growth regulators in plant disease. A. Rev. Phytopath. I, 5.

Shantz, E. M. \& Steward, F. C. (1955). The identification of compound A from coconut milk as I,3-diphenylurea. J. Am. chem. Soc. 77, 635I.

Shaw, M. (1963). The physiology and host-parasite relations of the rusts. A. Rev. Phytopath. 1, 259.

THROWER, L. B. (1965). Host physiology and obligate fungal parasites. Phytopath. Z. 4, 319.

Tulecke, W., Weinstein, L. H., RUtner, A. \& Laurencot, H. J. (I96I). The biochemical composition of coconut water as related to its use in plant tissue culture. Contr. Boyce Thompson Inst. Pl. Res. 2I, II5.

Wightman, F. (1962). Metabolism and biosynthesis of 3-indoleacetic acid and related indole compounds in plants. Can. J. Bot. $40,689$.

Williams, P. H. (1966). A cytochemical study of hypertrophy in clubroot of cabbage. Phytopathology 56,521 .

WINTER, A. (1966). A hypothetical route for the biogenesis of IAA. Plana 7r, 229.

WINTER, A. (1967a). The promotion of the immobilization of auxin in Avena coleoptiles by triiodobenzoic acid. Physiologia Plant 20, 330.

WINTER, A. $(1967 b)$. Antagonism of tryptamine stimulated growth in apices of Avena coleoptile by xylamidine tosylate. Nature, Lond. 216, 80r.

ZelleR, E. A. \& SARKER, S. (1962). Amine oxidases. XIX. Inhibition of monoamine oxidase by phenylcyclopropylamine and iproniazid. J. biol. Chem. 237, 2333. 
Journal of General Microbiology, Vol. 56, No. I

Plate I
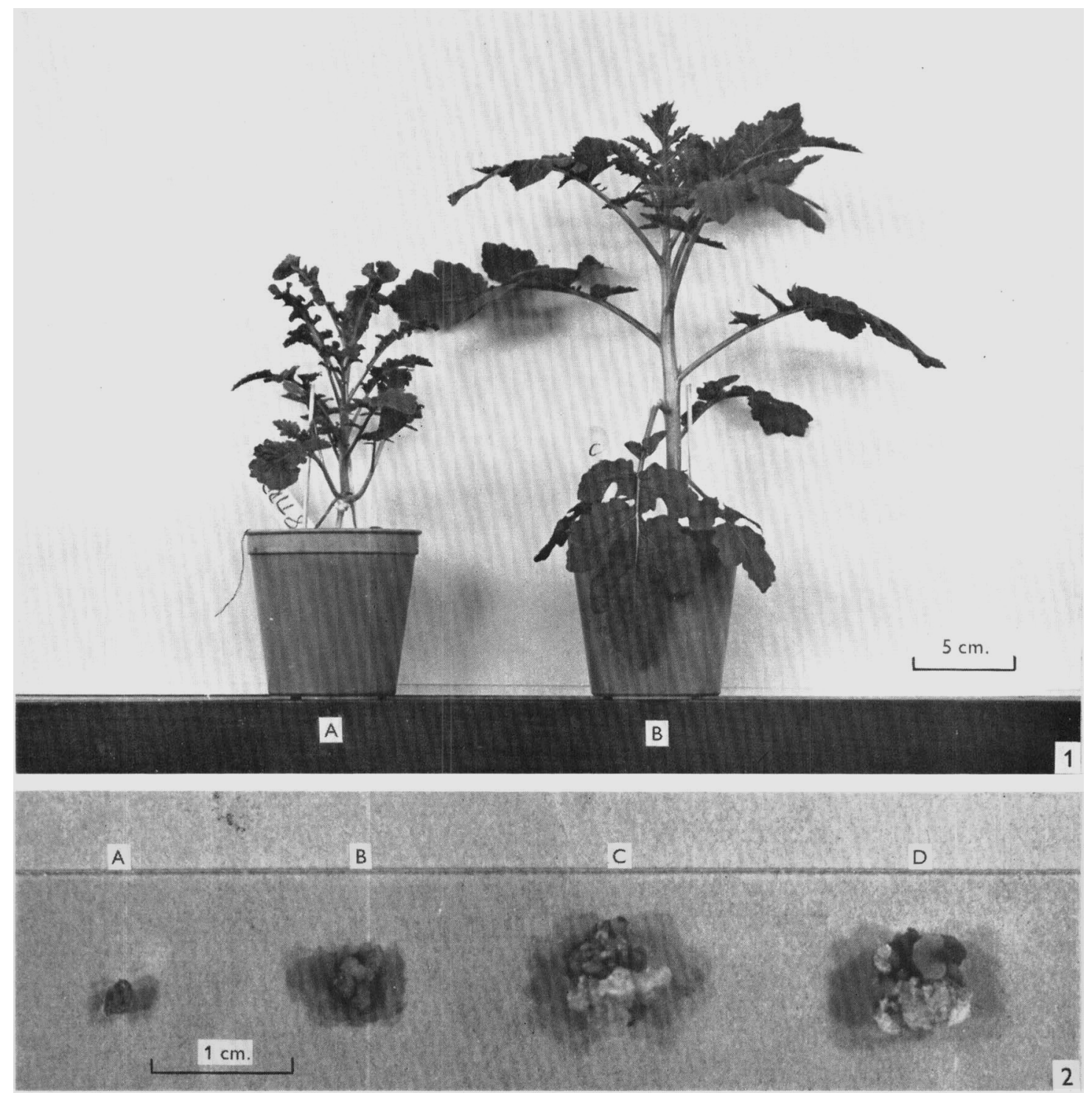

D. S. INGRAM

(Facing p. 66) 
Journal of General Microbiology, Vol. 56, No. I

Plate 2
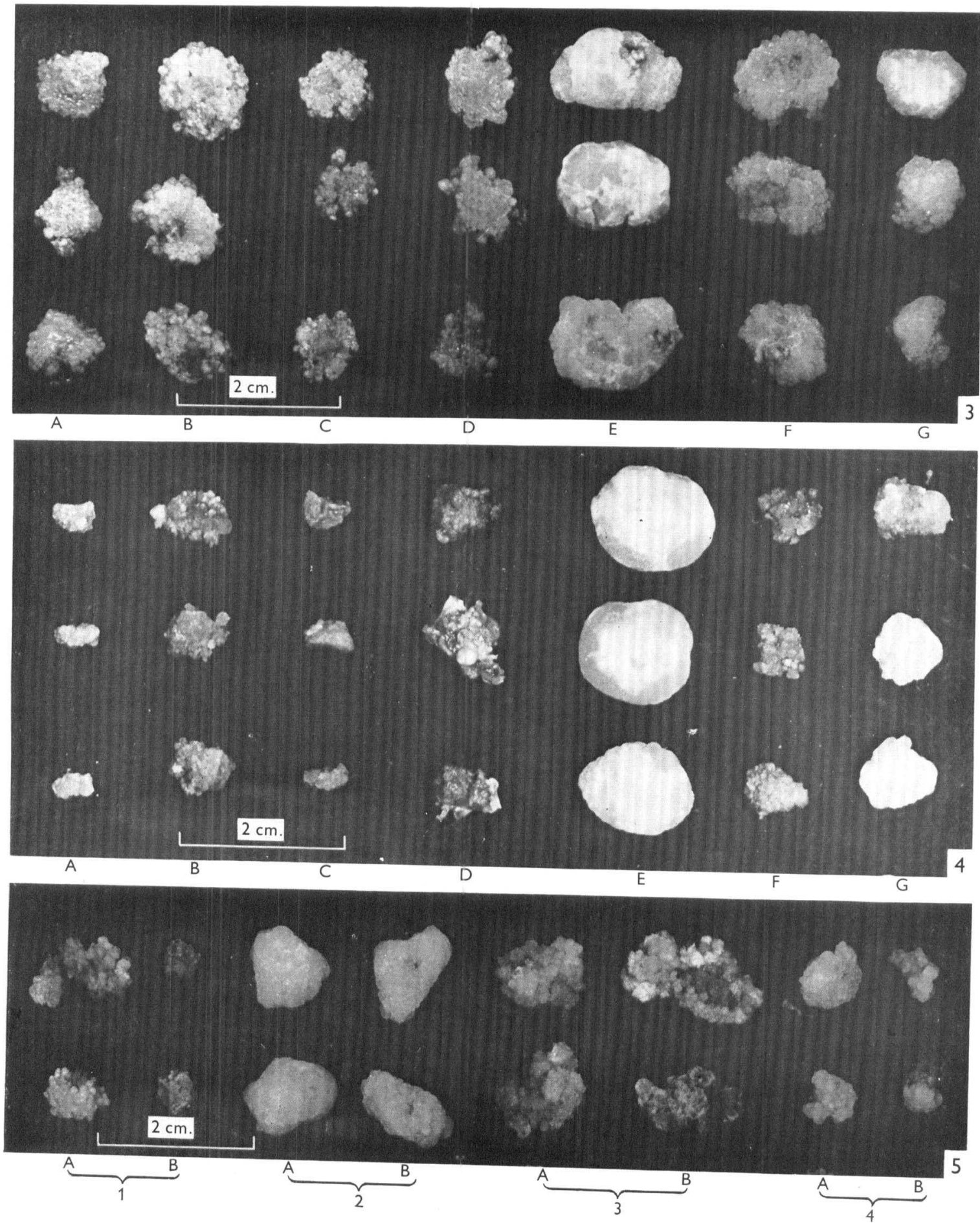

D. S. INGRAM 


\section{EXPLANATION OF PLATES}

Plate I

Fig. I. The effect of 2,3,5-triiodobenzoic acid (TIBA) on Sinapis alba after 35 days of growth in alternating $16 \mathrm{hr}$ dark and $8 \mathrm{hr}$. light periods. Hypocotyls of the plants were ringed at 7 days with: A, TIBA, $0.8 \%$ in lanolin; B, pure lanolin.

Fig. 2. Callus formed by explants of tissue from an uninfected root and a Plasmodiophora brassicae clubbed root of Brassica rapa (Balmoral Turnip) after 2 I days incubation on basal medium (no growth substances) and on coconut milk medium (2,4-dichlorophenoxyacetic acid $6.0 \mathrm{mg}$. $/ 1$. $+\alpha$-naphthyacetic $0.1 \mathrm{mg} . / 1 .+$ coconut milk $\mathrm{I} 50 \mathrm{ml} . / \mathrm{l}$.). A, Uninfected tissue on basal medium; B, uninfected tissue on coconut milk medium; $\mathrm{C}$, infected tissue on basal medium; $\mathrm{D}$, infected tissue on coconut milk medium.

\section{Plate 2}

Fig. 3, 4. Three replicate examples each of Brassica rapa (Golden Ball Turnip) callus infected with vegetative plasmodia of Plasmodiophora brassicae (Fig. 3) and uninfected Golden Ball callus (Fig. 4) after 8 weeks of growth on basal medium supplemented as follows: A, no supplements; B, $\alpha$-naphthylacetic acid (NAA) $0.5 \mathrm{mg} . / 1 .+$ kinetin $1.0 \mathrm{mg} . / 1$; C, kinetin $1.0 \mathrm{mg} . / 1$; D, NAA $0.5 \mathrm{mg} . / 1$. E, 2,4-dichlorophenoxyacetic acid (2,4-D) $6.0 \mathrm{mg}$. $/ 1$. + NAA $0.1 \mathrm{mg} . / 1$ + coconut milk $150 \mathrm{ml} . / 1$; F, coconut milk $150 \mathrm{ml}$./1.; G, 2,4-D 6.0 mg./1. + NAA $0.1 \mathrm{mg} . / 1$.

Fig. 5. Two replicate examples each of Brassica rapa (Golden Ball Turnip) callus infected with; vegetative plasmodia of Plasmodiophora brassicae after 8 weeks of growth on unsupplemented media (A) and on media supplemented with xylamidine tosylate $50.0 \mathrm{mg} . / \mathrm{l}$. (B). I, Basal medium; 2 , basal+ 2,4-dichlorophenoxyacetic acid (2,4-D) $6.0 \mathrm{mg}$./1. + $\alpha$-naphthylacetic acid (NAA) $0.1 \mathrm{mg} . / 1$. + coconut milk $150 \mathrm{ml} . / 1 ; 3$, basal + coconut milk $150 \mathrm{ml}$./1.; 4, basal + 2,4-D 6.0 mg./l. + NAA 0.1 mg./l. 